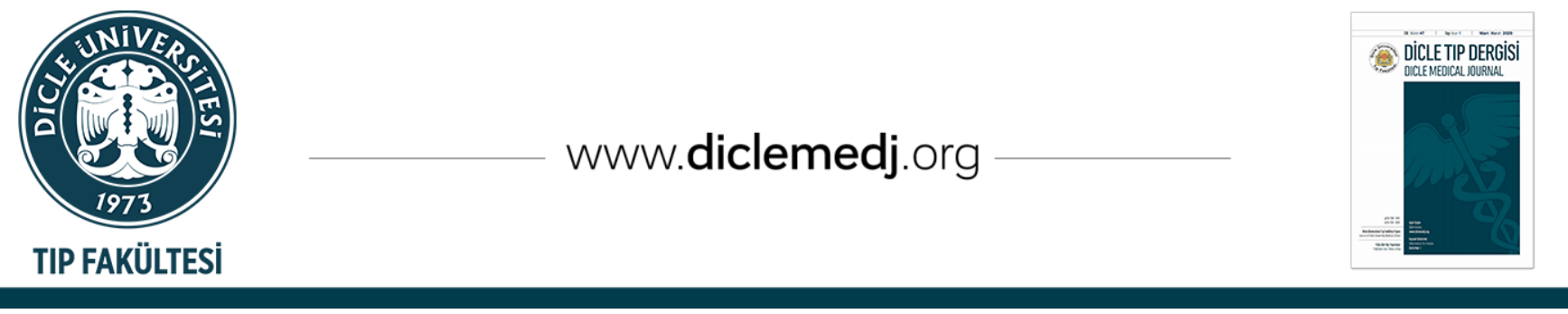

Özgün Araştırma / Original Article

\title{
Böbrek Biyopsilerinin Histopatolojik Değerlendirilmesi: Tek Merkez Yedi Ylllık Deneyim
}

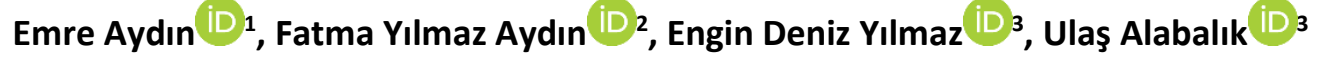 \\ 1 Dicle Üniversitesi Tıp Fakültesi Nefroloji Bilim Dalı, Diyarbakır, Türkiye \\ 2 Dicle Üniversitesi Tıp Fakültesi İç Hastalıkları Anabilim Dalı, Diyarbakır, Türkiye
}

3 Dicle Üniversitesi Tıp Fakültesi Tıbbi Patoloji Bilim Dalı, Diyarbakır, Türkiye

Geliş: 06.03.2020; Revizyon: 07.05.2020; Kabul Tarihi: 10.05.2020

Öz

Amaç: Böbrek biyopsisi, böbrek parankimal hastalıkların histopatolojik tanısının konulmasında sıklıkla kullanılan altın standart bir yöntemdir. Böbrek biyopsi kayıtları ile böbrek hastalıklarının epidemiyolojisi belirlenir. Literatürdeki çalışmalar incelendiğinde proteinüri en sık böbrek biyopsi endikasyonu olarak karşımıza çıkmaktadır. Glomerulonefritler ise en sık (GN) görülen histopatolojik sonuçlar olmaktadır. GN histopatolojik alt tiplerinin dağılımı ise coğrafi bölge, yaş, etnik kökene göre değiş̧ebilmektedir. Bizde bu çalışmada bölgemizdeki böbrek biyopsi sonuçlarına göre erişkin nefropati profilini tespit etmeyi amaçladık. Çalışmanın sonuçları aynı zamanda GN olgularının yaş ve cinsiyete göre sıklığının belirlenmesine de yardımcı olacaktır.

Yöntemler: Dicle Üniversitesi Tıp Fakültesi Nefroloji Kliniğinde Ocak 2011-Aralık 2017 yılları arasında ultrason eşliğinde perkütan böbrek biyopsisi yapılıp tanısı konulan 441 hastanın dosyası retrospektif olarak incelendi. Çalışmaya dahil edilen hastaların cinsiyet, yaş, biyopsi tarihi, histopatolojik tanısı değerlendirildi. Yıllara göre biyopsi yapılan hasta sayıları analiz edildi. Ayrıca cinsiyete ve yaşa göre biyopsi tanıları incelendi. Hastalar 18-39 yaș, 40-59 yaş ve 60 yaş üstü diye 3 gruba ayrıld.

Bulgular: Hastaların \%53.7'si (n=237) erkek, \%46.3 (n=204) kadındı. Ortalama yaş 37.4 olup erkeklerin yaş ortalaması 39.9, kadınların 34.5 yıl idi. Tüm yaş ve cinsiyet gruplarında en sık görülen histopatolojik tanılar FSGS (\%21.8), Membranöz GN (\%20.4) ve IgA Nefropatisi (\%11.6) olup; erkeklerde en sık Membranöz GN (\%21.9), kadınlarda en sık FSGS (\%24) olarak saptandı. 18-39 yaș arası 225 hastada en sık FSGS, 40-59 yaş arası 164 hastada en sık Membranöz GN, 60 yaş üstü 52 hastada ise en sık KTIN tanısı konuldu.

DOI: 10.5798/dicletip.755763

Correspondence / Yazışma Adresi: Emre Aydın, Dicle Üniversitesi Tıp Fakültesi İç Hastalıkları AD/ Nefroloji BD. Diyarbakır, Türkiye e-mail: emreaydin83@hotmail.com 
Sonuç: Bölgemizde erişkin böbrek biyopsi sonuçları göstermektedir ki FSGS, Membranöz GN ve IgA nefropatisi en sik görülen primer glomerülopatilerdir. Sekonder GN’ler içerisinde en sık Lupus Nefriti ve Amiloidoz görülmektedir. Yaşla birlikte glomeruler hastalıklar azalmaktayken, Kronik Tubulointertisyel hastalıkların ve Amiloidozun sıklı̆̆ı artmaktadır. Çalışmamızdaki sonuçlar ülkemizdeki böbrek biyopsi verileri ile benzerdi.

Anahtar kelime: böbrek, biyopsi, histopatoloji, glomerulonefrit

\title{
Histopathological Evaluation of Renal Biopsies: A Single Center, Seven Years Experience
}

\begin{abstract}
Objectives: Kidney biopsy is a gold standard method that is frequently used to make the histopathological diagnosis of kidney parenchymal diseases. Epidemiology of kidney diseases is determined by kidney biopsy records. When studies in the literature are examined, proteinuria is the most common indication for kidney biopsy. Glomerulonephritis (GN) is the most common histopathological results. Distribution of GN histopathological subtypes may vary according to geographical region, age, ethnicity. In this study, we aimed to determine the adult nephropathy profile according to kidney biopsy results in our region. The results of the study will also help determine the frequency of GN cases by age and gender.

Method: The data of 441 patients who underwent ultrasound guided percutaneous kidney biopsy between January 2011 and December 2017 at Dicle University Medical Faculty Nephrology Clinic were retrospectively analyzed. The gender, age, biopsy date and histopathological diagnosis of the patients included in the study were evaluated. The number of patients undergoing biopsy by years was analyzed. In addition, biopsy diagnoses by sex and age were examined. The patients were divided into 3 groups: 18-39 years, 4059 years and over 60 years.

Results: $53.7 \%(n=237)$ of the patients were male and $46.3 \%(n=204)$ were female. The average age was 37.4 years and the average age of men was 39.9 years and 34.5 years for women. The most common histopathological diagnoses in all age and gender groups were FSGS (21.8\%), Membranous GN (20.4\%) and Ig A Nephropathy (11.6\%); the most common subtypes were Membranous GN (21.9\%) in males, FSGS (24\%) in females. FSGS was the most common in 225 patients between the ages 18-39, membranous GN was the most common in 164 patients between the ages of 40-59, and CTIN was the most common in 52 patients over the age of 60.

Conclusion: Adult kidney biopsy results show that FSGS, Membranous GN and IgA nephropathy are the most common primary glomerulopathies in our region. Lupus Nephritis and Amyloidosis are the most common among secondary GNs. While glomerular diseases decrease with age, the frequency of chronic tubulointerstitial diseases and Amyloidosis increases. The results of our study were similar to kidney biopsy data in our country.
\end{abstract}

Keywords: Kidney, biopsy, histopathology, glomerulonephrit

\section{GíRiş}

Böbrek biyopsisi, böbrek parankimal hastalıkların histopatolojik tanısının konulması için sıklıkla kullanılan altın standart bir yöntemdir. Ultrason eşliğinde perkütan böbrek biyopsisi en sık kullanılan yöntem olup, yapılamadığı durumlarda açık böbrek biyopsisi veya laparoskopik böbrek biyopsisi yapılabilir. İdeal bir böbrek biyopsi örneği analizi belirli bir tanıyı göstermeli, hastalık aktivitesinin derecesini yansıtmalı, prognoz hakkında bilgi vermeli ve tedavi modalite seçiminde doğru kararları verebilmemizi sağlayacak bilgileri içermelidir.

Glomerulonefritlerin patogenezinde farklı oluşum mekanizmalarının benzer morfolojik bulgular ile karşımıza çıkması hastalıkların ayırıcı tanısını zorlaştırmaktadır. Ayrıca, tanıyı koyduracak bulguya sahip glomerül sayısının az olması, alınan böbrek dokusunun sınırlı parankim alanı içermesi ve hastalığın ileri dönemlerinde kronik bulguların ortak oluşu nedeni ile de ayırıcı tanıda zorluklar yaşanabilmektedir. Doğru tanı için biyopsi örneği yeterliliğinin yanı sıra dokuyu hazırlamada kullanılan teknik ve hastaya ait klinik bilgilerden patoloğun haberdar olması da önemlidir ${ }^{1}$.

Böbrek biyopsi endikasyonları arasında farklı ek göstergeler de göz önüne alınmak kaydıyla, nefrotik-nefritik düzeyde proteinüri, uzamış akut böbrek hasarı, renal fonksiyon bozukluğunun eşlik ettiği sistemik hastalıklar, 
izole mikroskopik hematüri, nedeni açıklanamayan kronik böbrek hastalığı, ailesel böbrek hastalıkları ve renal transplant fonksiyon bozukluğu yer almaktadır². Yapılan böbrek biyopsi kayıtları ile böbrek hastalıklarının epidemiyolojisi belirlenir. Dünya çapında epidemiyolojik çalışmalar incelendiğinde en sı böbrek biyopsi endikasyonu glomeruler proteinüridir ${ }^{3}$.

Ülkemizde farklı merkezlerin böbrek biyopsi sonuçlarını klinik ve patolojik açıdan değerlendiren yol gösterici çalışmalar bulunmaktadır. Ancak bölgemizde böbrek biyopsi sonuçlarının değerlendirildiği bir çalışma bulunmamaktadır. Bizde bu çalışmayla bölgemizdeki böbrek biyopsi sonuçlarını inceleyerek erişkin nefropati profilini tespit etmeyi amaçladık. Çalışmanın sonuçları, bölgemizdeki histopatolojik tanısı konulmuş olan GN olgularının yaş, cinsiyete göre sıklığının belirlenmesine yardımcı olacaktır.

\section{YÖNTEMLER}

Dicle Üniversitesi Tıp Fakültesi Nefroloji Kliniğinde 01 Ocak 2011-31 Aralık 2017 yılları arasında ultrason eşliğinde perkütan böbrek biyopsisi yapılıp tanısı konulan 441 hastanın dosyası retrospektif olarak incelendi. 18 yaş altında olan ve biyopside tanısı konulamayan hastalar çalışma dışına alındı. Nefrotik sendrom, nefritik sendrom, nedeni açıklanamayan izole makroskopik-mikroskopik hematüri, asemptomatik üriner anormallik, $\mathrm{ABH}$ ve $\mathrm{KBH}$ tanıları konulan hastaların etyolojisini belirlemek üzere böbrek biyopsisi yapıldı. Alınan böbrek biyopsi örnekleri HematoksilenEozin, PAS, PAMS, Trikrom, Kongo kırmızısı ve Kristal viole ile boyanarak ışık mikroskopisinde, IgA, IgG, IgM, C3, C1q, kappa ve lambda hafif zincirler, fibrinojen ve albümin ile direk immünfloresan boyama yapılarak immünfloresan yöntemle incelendi. Tek glomerül izlenen bazı biyopsi örneklerinde amiloidoz tanısı konulduğundan biyopsi yeterliliği açısından belirli bir glomerül sayısı eşik değer olarak alınmadı. Çalışmaya dahil edilen hastaların cinsiyet, yaş, biyopsi tarihi, histopatolojik tanısı değerlendirildi. Histopatolojik tanısına onaylanmış patoloji raporlarından ulaşıldı. Yıllara göre yapılan biyopsi sayıları, cinsiyete ve yaşa göre biyopsi tanılarına bakıldı. Hastalar $18-39$ yaş, $40-59$ yaş ve 60 yaş üstü diye 3 gruba ayrıldı. Dicle Üniversitesi Tıp Fakültesi 09.01.2020 tarih ve 36 sayı numaralı etik kurul onayı alınmıştır.

\section{BULGULAR}

Çalışmaya Ocak 2011-Aralık 2017 yılları arasında böbrek biyopsisi yapılıp tanı konulan 441 hasta dahil edildi. En fazla biyopsi 2017 yllında \%20,2 (n=89) yapıldı. Yıllara göre biyopsi yapılan hasta sayısı Şekil 1'de gösterilmiştir. Hastaların \%53,7'si $\quad(n=237)$ erkek, \%46,3 ( $\mathrm{n}=204)$ kadındı. Ortalama yaş 37.4 (minimum 18- maksimum 80) olup erkeklerin yaş ortalaması 39.9, kadınların 34.5 yll idi.

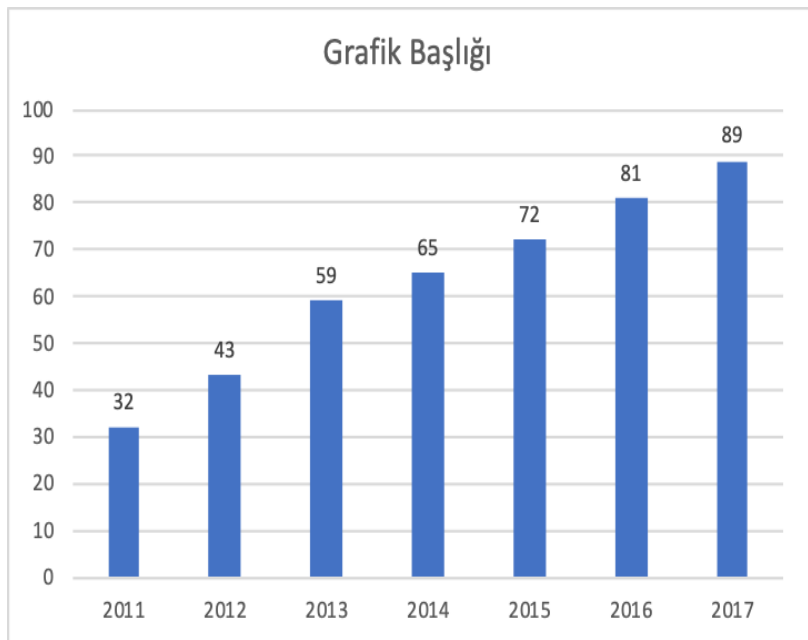

Şekil 1. Yıllara göre biyopsi yapılan hasta sayısı

Biyopsi sonuçlarına cinsiyet ayrımı yapılmadan bakıldığında en sık FSGS $(\% 21,8)$ görülürken sırasıyla Membranöz Glomerulonefrit $(\% 20,4)$, IgA Nefropatisi $(\% 11,6)$ ve Kronik Tubulointertisyel Nefrit (KTIN) $(\% 11,3)$ diğer slk nedenler olarak tespit edildi. Şekil 2'de biyopsi tanılarının dağılımı gösterilmektedir. 
Erkeklerde sırasıyla en sik Membranöz GN $(\% 21,9), \quad$ FSGS $(\% 19,8)$, IgA Nefropatisi (\%12,7), KTIN (\%11) saptanırken, kadınlarda en sık FSGS (\%24), Membranöz GN $(\% 18,6)$, Lupus Nefriti $(\% 14,6)$, KTIN $(\% 11,8)$ yer aldı. Histopatolojik tanıların cinsiyete göre dağılımı Tablo I'de gösterilmiştir.

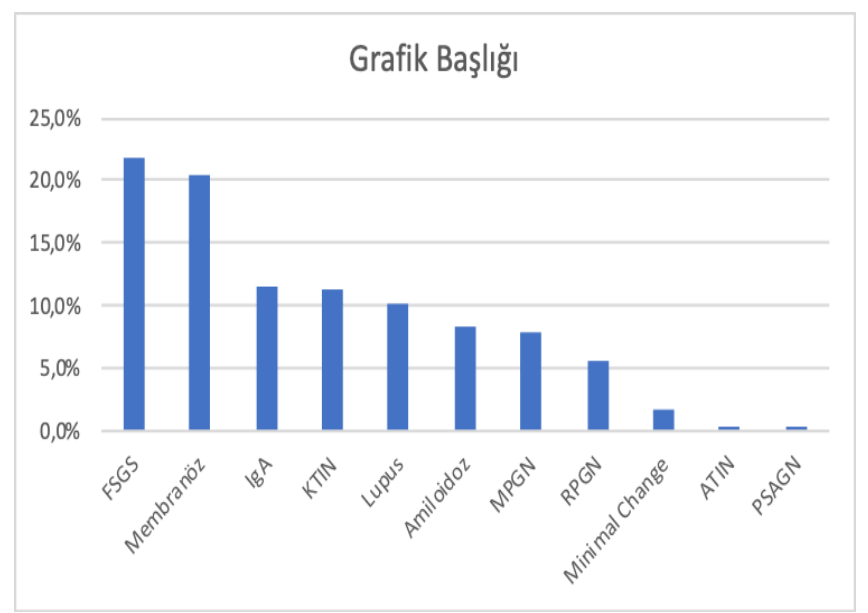

Şekil 2. Biyopsi tanılarının dağılımı

Tablo I: Histopatolojik tanıların cinsiyete göre dağılımı

\begin{tabular}{|l|l|l|l|l|l|l|}
\hline \multirow{2}{*}{ TANI } & \multicolumn{2}{l|}{ ERKEK } & \multicolumn{2}{l|}{ KADIN } & \multicolumn{2}{l|}{ TOPLAM } \\
\cline { 2 - 7 } & $\mathrm{n}$ & $\%$ & $\mathrm{n}$ & $\%$ & $\mathrm{n}$ & $\%$ \\
\hline FSGS & 47 & $19,8 \%$ & 49 & $24,0 \%$ & 96 & $21,8 \%$ \\
\hline Membranöz GN & 52 & $21,9 \%$ & 38 & $18,6 \%$ & 90 & $20,4 \%$ \\
\hline IgA Nefropatisi & 30 & $12,7 \%$ & 21 & $10,4 \%$ & 51 & $11,6 \%$ \\
\hline KTIN & 26 & $11,0 \%$ & 24 & $11,8 \%$ & 50 & $11,3 \%$ \\
\hline Lupus Nefriti & 15 & $6,3 \%$ & 30 & $14,6 \%$ & 45 & $10,2 \%$ \\
\hline MPGN & 24 & $10,1 \%$ & 13 & $6,4 \%$ & 37 & $8,3 \%$ \\
\hline RPGN & 21 & $8,9 \%$ & 14 & $6,8 \%$ & 35 & $7,9 \%$ \\
\hline Minimal Change D. & 6 & $2,5 \%$ & 2 & $1,0 \%$ & 8 & $1,8 \%$ \\
\hline ATIN & 2 & $0,9 \%$ & 0 & $0,0 \%$ & 2 & $0,5 \%$ \\
\hline PSAGN & 1 & $0,4 \%$ & 1 & $0,5 \%$ & 2 & $0,5 \%$ \\
\hline TOPLAM & $\mathbf{2 3 7}$ & $\mathbf{1 0 0 , 0}$ & $\mathbf{2 0 4}$ & $\mathbf{1 0 0 , 0}$ & $\mathbf{4 4 1}$ & $\mathbf{1 0 0 , 0}$ \\
\hline & & & & $\%$ & & $\%$ \\
\hline
\end{tabular}

18-39 yaş arası 225 (\%51), 40-59 yaş arası 164 $(\% 37,2), \quad 60$ yaş üstü $52 \quad(\% 11,8)$ hasta mevcuttu. Yaş gruplarınıza baktığımızda 18-39 yaş arası grupta sırasıyla en sik FSGS, Membranöz GN, IgA Nefropatisi, Lupus Nefriti; 40-59 yaș grubunda en sık Membranöz GN, FSGS, KTIN, Amiloidoz; 60 yaş üstü grupta ise en sık KTIN, FSGS, Amiloidoz tanısı konulduğu saptandı. Böbrek biyopsilerinin histopatolojik tanıları ve yaşa göre dağılımı Tablo II'de gösterilmiştir.

Tablo II: Böbrek biyopsilerinin histopatolojik tanıları ve yaşa göre dağılımı.

\begin{tabular}{|l|l|l|l|l|l|l|l|l|l|}
\hline \multirow{2}{*}{ TANI } & \multicolumn{2}{|l|}{$18-39$ Yaş } & \multicolumn{2}{l|}{ 40-59 Yaş } & \multicolumn{2}{l|}{ 60 Yaş üstü } \\
\cline { 2 - 10 } & E & K & $\begin{array}{l}\text { TOPL } \\
\text { AM }\end{array}$ & E & K & $\begin{array}{l}\text { TOPL } \\
\text { AM }\end{array}$ & E & K & $\begin{array}{l}\text { TOPL } \\
\text { AM }\end{array}$ \\
\hline FSGS & 23 & 24 & 47 & 20 & 18 & 38 & 4 & 7 & 11 \\
\hline Membranöz & 21 & 21 & 42 & 27 & 17 & 44 & 4 & 0 & 4 \\
\hline Nefropatisi & 23 & 17 & 40 & 7 & 4 & 11 & 0 & 0 & 0 \\
\hline KTIN & 7 & 4 & 11 & 11 & 12 & 23 & 8 & 8 & 16 \\
\hline Lupus Nefriti & 10 & 25 & 35 & 2 & 5 & 7 & 3 & 0 & 3 \\
\hline Amiloidoz & 6 & 7 & 13 & 10 & 5 & 15 & 8 & 1 & 9 \\
\hline MPGN & 8 & 10 & 18 & 9 & 4 & 13 & 4 & 0 & 4 \\
\hline RPGN & 4 & 5 & 9 & 7 & 5 & 12 & 2 & 2 & 4 \\
\hline Minimal & 6 & 2 & 8 & 0 & 0 & 0 & 0 & 0 & 0 \\
\hline Change D. & 1 & 0 & 1 & 0 & 0 & 0 & 1 & 0 & 1 \\
\hline TTIN & 0 & 5 & 11 & 0 & 1 & 1 & 0 & 0 & 0 \\
\hline
\end{tabular}

\section{TARTIŞMA}

Primer glomeruler hastalıklar (PGH) son dönem böbrek yetmezliğinin önemli nedenlerinden biridir. Ülkemizde Türk Nefroloji Derneği'nin (TND) 2018 verilerine göre kronik hemodiyaliz programında olan hastaların etyolojisine bakıldığında üçüncü sıklıkta glomerülonefritler 
karşımıza çıkmaktadır ${ }^{4}$. Böbrek biyopsisi başta glomerülonefritler olmak üzere böbreğin glomerüler ve tübüler hastalıkların tanısını koymada altın standart bir yöntemdir ${ }^{5}$. Böbrek biyopsisinin pek çok endikasyonu olmakla birlikte en slk glomeruler proteinüri bildirilmektedir ${ }^{3}$.

Çalışmaya 2011-2017 yılları arasında böbrek biyopsi sonuçlarına ulaştığımız hastalar alındı. Hastaların \%53,7'ı erkek olup hastaların ortalama yaşı 37.4 idi. Bu bulgular ülkemizdeki ve dünyadaki çoğu çalışmayla benzerlik göstermektedir6-9.

Böbrek biyopsi

sonuçlarını değerlendirdiğimizde yaş ve cinsiyet ayrımı yapılmaksızın tüm olguların \%87,7'sinde glomerüler hastalık tespit ettik. Primer GN'ler \%63,5'ini oluştururken sekonder GN'ler \%24,2 oranındaydı. Primer GN tanısı konan hastalarda en sık görülen alt tipler sırasıyla FSGS $(\% 21,8)$, Membranöz GN $(\% 20,4)$ ve IgA Nefropatisi $(\% 11,6) \quad$ şeklindeydi. Literatürü incelediğimizde; Ecder ve arkadaşlarının 2005 yılında yaptığı ve 513 olgunun değerlendirildiği çalışmada böbrek biyopsi sonuçlarına göre en sık IgA Nefropatisi $(\% 11,9)$ tanısı konulmuş olup bunu sırasılyla kresentik GN, Membranöz GN izlemiştir7. Akarsu ve arkadaşlarının 105 hastayı değerlendirdiği çalışmada ise en sık Membranöz GN $(\% 22,9)$ tanısı konulmuş, bunu FSGS ve MPGN izlemiştir ${ }^{10}$. Tekin ve arkadaşlarının 2018 yılında yaptığı 506 böbrek biyopsisinin değerlendirildiği çalışmada da en sık Membranöz GN $(\% 15,8)$ sonra sirasiyla FSGS ve Ig A nefropatisi bildirilmiştir ${ }^{11}$. Ülkemizde yapılan bir başka çalışmada ise Hür ve arkadaşları primer GN'ler içerisinde en sık FSGS $(\% 10,28)$ tespit etmiş, Membranöz GN ve IgA Nefropatisi diğer patolojik tanıları oluşturmuştur ${ }^{12}$. Öztürk ve arkadaşları tarafından TND ulusal veri tabanı esas alınarak ülkemizde yapılmış çok merkezli toplam 1274 hastanın değerlendirildiği çalıșmada ise en sık Membranöz GN $(\% 28,8)$, ikinci slklıkta ise FSGS
$(\% 19,3)$ saptandığı belirtilmiștir ${ }^{13}$. Ülkemizde yapılan çok sayıda çalışmanın sonuçlarına baktığımızda bizim çalışmamızla da uyumlu şekilde en sık görülen ilk üç primer GN; Membranöz GN, FSGS ve Ig A Nefropatisidir. Primer GN tiplerinin dağılımı ise coğrafi bölge, yaş, etnik köken, çalışmanın yapıldığı yılların farklılığına göre değișebilmektedir.

Çalışmamızda sekonder GN'lerin etyolojik değerlendirmesine baktığımızda en sık Lupus Nefriti $(\% 10,2)$ karşımıza çıkarken ikinci sıklıkta Amiloidoz $(\% 8,3)$ saptadık. Bu sıralama ülkemizde yapılan geniş çaplı çalışmaların sonuçları ile benzerlik göstermektedir7,10.

Ayrıca çalışmamızda, yaş ilerledikçe glomerüler hastalıkların oranı azalırken tübüler patolojilerin oranı artmaktaydı. Bununla beraber gruplarda GN'lerin patolojik alt tiplerinde de farklılıklar olduğu görüldü. Çalışmamızda yaş gruplarına baktığımızda 1839 yaş arası grupta sırasıyla en sık FSGS, Membranöz GN, IgA Nefropatisi, Lupus Nefriti; 40-59 yaş grubunda en sık Membranöz GN, FSGS, KTIN, Amiloidoz; 60 yaș üstü grupta ise en sık KTIN, FSGS, Amiloidoz tanısı olduğunu tespit ettik. Klasik literatür bilgisine benzer şekilde, genç yaşta daha sık karşılaşılan IgA Nefropatisi ile Lupus Nefritinin yaş ilerledikçe görülme sıklığının azaldığı, KTIN ve Amiloidoz oranının arttığını saptadık.

Sonuç olarak çalışmamızda sık görülen Primer GN'ler; FSGS, Membranöz GN, ve IgA nefropatisi olup ülkemizde yapılan benzer çalışmalarda da sırası değişmekle beraber bu patolojik tanılar ilk üç sırayı almaktadır. Sekonder GN'ler içerisinde ise en sık Lupus Nefriti ve Amiloidoz görülmektedir. Çalışmamız tek merkez deneyimini yansıtmakla beraber, elde ettiğimiz bulgular bölgemizde sık görülen renal patolojilerin dağılımını göstermektedir. $\mathrm{Bu}$ çalışmanın Güneydoğu Anadolu Bölgesi adına oldukça değerli ve yol gösterici olacağı kanaatindeyiz. 
Etik Kurul Kararı: Dicle Üniversitesi Tıp Fakültesi 09.01.2020 tarih ve 36 sayı numaralı etik kurul onayı alınmıştır.

Çıkar Çatışması Beyanı: Yazarlar çıkar çatışması olmadığını bildirmişlerdir.

Finansal Destek: Bu çalışma her hangi bir fon tarafından desteklenmemiştir.

Declaration of Conflicting Interests: The authors declare that they have no conflict of interest.

Financial Disclosure: No financial support was received.

\section{KAYNAKLAR}

1. Öztürk S. Primer Glomerüler Hastalıkların Tanı ve Tedavisi. Türk Nefroloji Derneği Ulusal Uzlaşı Raporu. Türk Nefroloji Derneği Yayınları. 2019: 27-8.

2. Topham PS, Chen Y. Comprehensive Clinical Nephrology, 6th ed, Elsevier. Renal Biopsy, 2018; 72-9.

3. Agarwal SK, Sethi S, Dinda AK. Basics of kidney biopsy: A nephrologist's perspective. Indian J Nephrol. 2013 Jul; 23: 243-52.

4. Süleymanlar G, Ateș K, Seyahi N. Türkiye'de Nefroloji Diyaliz ve Transplantasyon. Ankara: Türk Nefroloji Derneği, 2019; 1-128.

5. Yılmaz T, Alp A, Akdam H, et al. Böbrek Biyopsisi Yapılan Olgularımızın Retrospektif Genel Değerlendirilmesi ve Histopatolojik Alt Gruplarının İncelenmesi. Turk Neph Dial Transpl. 2014; 23: 185-95.

6. Okpechi I, Swanepoel C, Duffield M, et al. Patterns of renal disease in Cape Town South Africa: A 10-year review of a single-centre renal biopsy database. Nephrol Dial Transplant. 2011; 26: 1853-61.
7. Ecder SA, Kılıçaslan I, Ecder T, et al. Beş yüz on üç böbrek biyopsisinin klinikopatolojik açıdan değerlendirilmesi. İstanbul Tıp Fakültesi Dergisi 2005; 68: 43-5.

8. Gürel A, Aygen B, Düzenci D, et al. Nefroloji Kliniğimizin Üç Yıllık Dönemde Erişkinlerde Ultrason Yardımlı Perkütan Böbrek Biyopsisi Deneyimi: Klinikopatolojik Bir Değerlendirme. F.Ü.Sağ.Bil.Tıp Derg. 2012; 26: 107-9.

9. Zhou FD, Shen HY, Chen M, et al. The renal histopathological spectrum of patients with nephrotic syndrome: An analysis of 1523 patients in a single Chinese centre. Nephrol Dial Transplant. 2011; 26: 3993-7.

10. Akarsu Ö, Aytuğ F, Yavuz A, et al. Hastanemiz Nefroloji Kliniğinde Böbrek Biyopsisi Yapılan Olguların Özelliklerinin Değerlendirilmesi. Turk Neph Dial Transpl. 2016; 25: 245-50.

11. Tekin E, Diniz G, Karadeniz T, Akar H, Yavaşcan Ö. Böbrek biyopsilerinin histopatolojik profili: Tek merkez, dört yıllık deneyim. Tepecik Eğit. Ve Araşt. Hast. Dergisi. 2018; 28: 181-6.

12. Hur E, Taskin H, Bozkurt D, et al. Adult native renal biopsy experience of Ege University for 12 consecutive years. BANTAO Journal. 2010; 8: 22-9.

13. Öztürk S, Sumnu A, Seyahi $\mathrm{N}$, et al. Demographic and clinical characteristics of primary glomerular diseases in Turkey. Int Urol Nephrol. 2014; 46: 2347-55. 